\title{
Den som har ører, han høre
}

\author{
En grundig klinisk undersøkelse kan avdekke så mangt.
}

I artikkelen En mann i 20-årene med magesmerter og bilyd over hjertet i Tidsskriftet nr. 3/2016 (1) har «bilyd» en fremtredende plass i overskriften. Imidlertid er bilydene nokså stemoderlig behandlet $i$ teksten.

Dette henger nok sammen med at $i$ vår teknifiserte sykehushverdag legges det stadig mindre vekt på kliniske funn. Dessuten er de forskjellige typene bilyd av mange ansett som vanskelige.

Omtalte pasient hadde fra tidligere diagnosen liten ventrikkelseptumdefekt. Den opprinnelig beskrevne systoliske bilyden passer med denne diagnosen.

To uker etter innleggelsen, etter at han hadde fått meget alvorlige symptomer og var til behandling i intensivavdeling, er det beskrevet systolisk pluss diastolisk bilyd. Dette passer meget dårlig med den konklusive diagnosen rumpert sinus valsalvaeaneurisme med stor shunt fra aorta til høyre atrium.

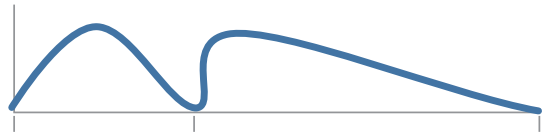

1. hjertetone 2. hjertetone

Figur 1 Systolisk pluss diastolisk bilyd

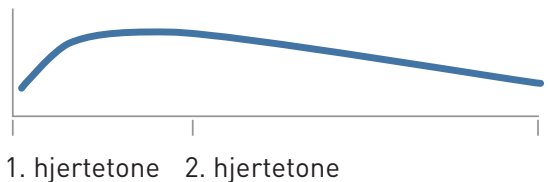

Figur 2 Kontinuerlig bilyd
Generelt kan bilyder deles i tre grupper: systoliske, diastoliske og kontinuerlige. De to førstnevnte er stort sett greie å forholde seg til, mens kontinuerlige bilyder er mindre påaktet.

\section{«| vår teknifiserte sykehushverdag legges det stadig mindre vekt på kliniske funn»}

Det typiske eksemplet på systolisk pluss diastolisk bilyd er aortastenose pluss aortainsuffisiens. Lydfenomenet har her et nullpunkt i det øyeblikket blodstrømmen snur ved overgangen fra systole til diastole (fig 1).

En kontinuerlig bilyd er definisjonsmessig en bilyd som går gjennom hele systolen og varer til etter 2. hjertetone. Oftest, men ikke alltid, vil den også fylle hele diastolen. Lyden vil oppstå når det skjer en shunting fra ett avsnitt til et annet gjennom hele hjertesyklusen. Det typiske eksemplet er åpenstående ductus arteriosus (unntatt i nyfødtperioden, da lungekarmotstanden fremdeles er relativt høy). Lydfenomenet har her ikke noe nullpunkt (fig 2).

Med litt trening er det sjelden vanskelig å skille mellom disse bilydtypene.

Med det beskrevne rumperte sinus valsalvae-aneurismet, der shunten var så stor at det medførte de beskrevne symptomer, er det opplagt at shuntingen hos denne pasienten skjedde både $\mathrm{i}$ systole og diastole. Man må derfor anta at bilyden som ble beskrevet som systolisk pluss diastolisk, egentlig var en kontinuerlig bilyd. Først langt ute i artikkelen nevnes i det hele tatt begrepet kontinuerlig bilyd, og da ikke i omtalen av det aktuelle tilfellet.

Siden pasienten ved innleggelsen var tydelig medtatt, kan man undres om det allerede da forelå en bilyd som ikke var rent systolisk, heller ikke systolisk pluss diastolisk, men kontinuerlig. Hadde man ut fra den kliniske undersøkelsen da erkjent en kontinuerlig bilyd, ville veien til den korrekte diagnosen trolig ha vært betydelig kortere.

Virkelig «noe å lære av» - nemlig at teknologi ikke erstatter klinisk undersøkelse!

\section{Petter S. Hagemo \\ pshagemo@broadpark.no}

Petter S. Hagemo (f. 1943) er pensjonert spesialist i barnesykdommer.

Forfatter har fylt ut ICMJE-skjemaet og oppgir ingen interessekonflikter.

\section{Litteratur \\ 1. Jortveit J, Dahlslett T, Kvien EH et al. En mann i 20 -årene med magesmerter og bilyd over hjertet. Tidsskr Nor Legeforen 2016; 136: 238-40.}

Mottatt 12.2. 2016 og godkjent 15.2. 2016. Redaktør: Ketil Slagstad.

Publisert først på nett. 